\title{
Effect of Plant Residues Application on Nitrogen Release From Plant Residues Previously Added
}

\author{
Abdelrauf. M .Saleh Alamin ${ }^{1,2}$, Didik Suprayogo ${ }^{3}$, and Eko Handayanto ${ }^{3}$ \\ ${ }^{1}$ Postgraduate Program, Faculty of Agriculture, Brawijaya University, Jl.Veteran, Malang 65145- Indonesia \\ ${ }^{2}$ Department program, Facultyof agriculture, Sebha University, Sebha city, Lybia. \\ ${ }^{3}$ Department of Soil Science, Faculty of Agriculture, Brawijaya University, Jl. Veteran, Malang 65145-Indonesia;
}

\begin{abstract}
This study was carried to effect of plant residues application on nitrogen release from plant residues previously added (rice straw=RS; soybean=SY) with ${ }^{15} \mathrm{~N}$ isotope dilution technique on growth of maize with application of Twelve treatments (six treatments of addition of new plant residues and six treatments of no addition of new plant residues were arranged in a randomized block design with three replicates for each treatment resulting total of 36 pots. Five pre-germinated seeds of maize were planted in each pot and thinned to four plants after 1 week. six types of ${ }^{15} \mathrm{~N}$ labelled plant residues, i.e. biomass of rice grown under $0.0625 \mathrm{mM} \mathrm{N}$ $\left(\mathrm{N}_{1} \mathrm{~T}_{1}\right), 0.250 \mathrm{mM} \mathrm{N}\left(\mathrm{N}_{2} \mathrm{~T}_{1}\right), 10.0 \mathrm{mM} \mathrm{N}\left(\mathrm{N}_{3} \mathrm{~T}_{1}\right)$ supplies, and biomass of soybean grown under $0.0625 \mathrm{mM} \mathrm{N}$ $\left(\mathrm{N}_{1} \mathrm{~T}_{2}\right), 0.250 \mathrm{mM} \mathrm{N}\left(\mathrm{N}_{2} \mathrm{~T}_{2}\right), 10.0 \mathrm{mM} \mathrm{N}\left(\mathrm{N}_{3} \mathrm{~T}_{2}\right)$ supplies. Fresh plant residue (unlabelled ${ }^{15} \mathrm{~N}$ ) used for this study was obtained by growing rice and soybean for 2 months under $10.0 \mathrm{mM} \mathrm{N}$ supplied as $\mathrm{CO}(\mathrm{NH} 2) 2$ in solution at the rate of $400 \mathrm{ml} /$ pot/day.

Soils $(10 \mathrm{~kg})$ from each pot of experiment previously conducted were split into two parts. The first part of $5 \mathrm{~kg}$ of soil was treated with addition of new plant residues accordingly (unlabelled rice residue and soybean residue, supplied with $10 \mathrm{mM} \mathrm{N}$ for 3 months). This treatment was aimed to examine the influence of addition of new plant residues on $\mathrm{N}$ release from previously added ${ }^{15} \mathrm{~N}$-labelled plant residues and $\mathrm{N}$ uptake by maize. No new plant residue was added to the second part of $5 \mathrm{~kg}$ of soil. This treatment was aimed to evaluate the residual $\mathrm{N}$ release from previously added ${ }^{15} \mathrm{~N}$-labelled plant residues and $\mathrm{N}$ uptake by maize.

This study concluded that rice straw residues amendment affect the soil fertility more than soybean residues sufficiently to improve growth of the subsequent crop.
\end{abstract}

Key words: Soybean, rice straw, ${ }^{15} \mathrm{~N}$ labelled, $N$ recovery, $N$ mineralization, $N$ uptake

\section{INTRODUCTION}

Declining soil organic matter in tropical soils that can be a major constraint for crop production may be overcome by application of plant residues as sources of organic matters. The efficiency with which $\mathrm{N}$ in plant residues is recovered by a crop depends on the rate at which the $\mathrm{N}$ is released relative to crop requirements. The rate of mineralization of $\mathrm{N}$ from plant residues depends on their chemical and physical properties, the environmental conditions and the decomposer communities. $\mathrm{N}$ recovery from added residues by the first subsequent crop is usually within the range of $10-30 \%$ for tropical plant residues.

Little attention has been given to the longer-term $\mathrm{N}$ mineralization and $\mathrm{N}$ recovery from plant residues. This is perhaps because $\mathrm{N}$ recoveries from plant residues in the second and following crop cycles are often only $5 \%$ or less of the amount originally applied. However, long-term $\mathrm{N}$ release may be of considerable practical interest, particularly for 'poor' quality residues as they provide little $\mathrm{N}$ benefit to the first crop.

In most natural or agricultural systems, plant residues are added to the soil repeatedly. Freshly added pruning may have a stimulatory 'priming' effect or a retarding effect on the decomposition of the plant residues applied previously

\subsection{Materials}

\section{MATERIAL AND METHODS}

Materials used for the study were soil, fresh plant residues (rice and soybean) and maize seeds (Arjuna variety). The soils were previously used for growing maize with application of six types of ${ }^{15} \mathrm{~N}$ labelled plant residues, i.e. biomass of rice grown under $0.0625 \mathrm{mM} \mathrm{N}\left(\mathrm{N}_{1} \mathrm{~T}_{1}\right), 0.250 \mathrm{mM} \mathrm{N}\left(\mathrm{N}_{2} \mathrm{~T}_{1}\right), 10.0 \mathrm{mM} \mathrm{N}\left(\mathrm{N}_{3} \mathrm{~T}_{1}\right)$ supplies, and biomass of soybean grown under $0.0625 \mathrm{mM} \mathrm{N}\left(\mathrm{N}_{1} \mathrm{~T}_{2}\right), 0.250 \mathrm{mM} \mathrm{N}\left(\mathrm{N}_{2} \mathrm{~T}_{2}\right), 10.0 \mathrm{mM} \mathrm{N}\left(\mathrm{N}_{3} \mathrm{~T}_{3}\right)$ supplies (Sholihah et al., 2012). Fresh plant residue (unlabelled $15 \mathrm{~N}$ ) used for this study was obtained by growing rice and soybean for 2 months under $10.0 \mathrm{mM} \mathrm{N}$ supplied as $\mathrm{CO}(\mathrm{NH} 2) 2$ in solution at the rate of 400 $\mathrm{ml} /$ pot/day. Others nutrients ( $\mathrm{Ca}, \mathrm{K}, \mathrm{P}, \mathrm{S}, \mathrm{Mg}, \mathrm{Cl}, \mathrm{Fe}, \mathrm{Mn}, \mathrm{Zn}, \mathrm{B}, \mathrm{Mo}$ and $\mathrm{Co}$ ) were also supplied in solution of Hammer et al. (1978). Prior to application to the soils, samples pf the plant residues were oven dried at $60 \mathrm{o} C$ for 48 hours and analyzed for polyphenol, lignin, $\mathrm{N}$, and C contents. The polyphenol was extracted in hot $50 \%$ 
aqueous methanol and determined colorimetrically using Folin-Denis method (Anderson \& Ingram, 1992). Lignin was determined as acid-detergent lignin (Goering \& Van Soest, 1970). The C and N content were determined respectively by Walkley and Black method and Kjeldahl method (Keeney and Nelson, 1982).

\subsection{Methods}

Soil $(10 \mathrm{~kg})$ from each pot of experiment previously conducted by Sholihah e.t. (2012) were split into two parts (Figure 1). The first part of $5 \mathrm{~kg}$ of soil was treated with addition of new plant residues accordingly (unlabelled rice residue and soybean residue, supplied with $10 \mathrm{mM} \mathrm{N}$ for 3 months). This treatment was aimed to examine the influence of addition of new plant residues on $\mathrm{N}$ release from previously added ${ }^{15} \mathrm{~N}$-labelled plant residues and $\mathrm{N}$ uptake by maize. No new plant residue was added to the second part of $5 \mathrm{~kg}$ of soil. This treatment was aimed to evaluate the residual $\mathrm{N}$ release from previously added ${ }^{15} \mathrm{~N}$-labelled plant residues and $\mathrm{N}$ uptake by maize.
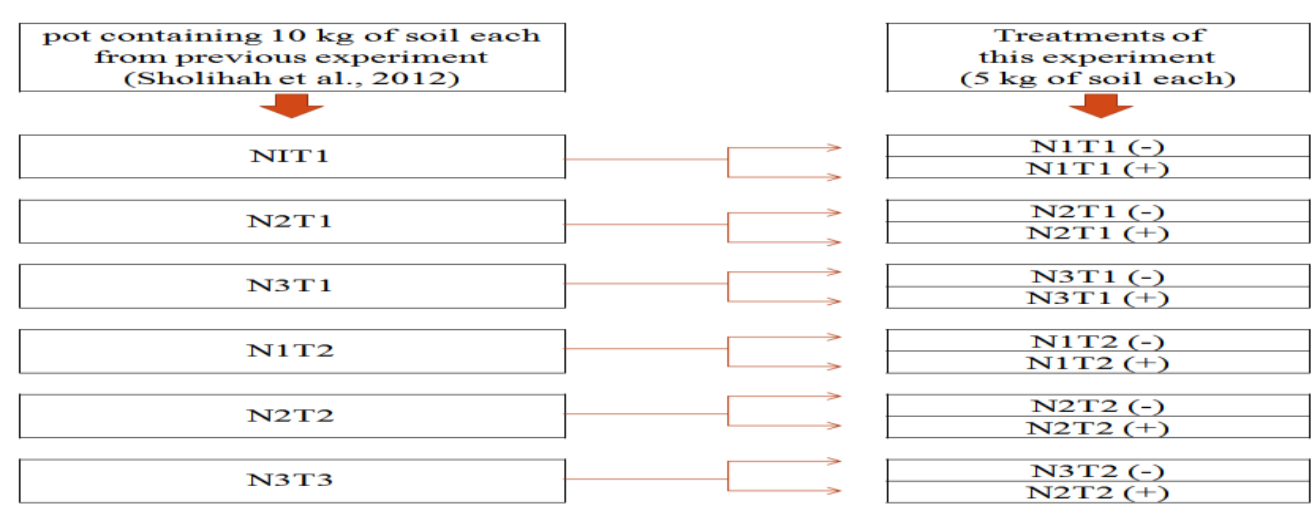

Figure 1: Treatments

The rate of new plant residue applied was equivalent to $20 \mathrm{t} / \mathrm{ha}$. Each pot received basal fertilizers of 28 $\mathrm{mg} \mathrm{P} / \mathrm{kg}$ (SP36), $25 \mathrm{mg} \mathrm{K} / \mathrm{kg}$ (K2SO4) and $2.5 \mathrm{mg} / \mathrm{Zn} / \mathrm{kg}$ (ZnSO4). The moisture content of the soil in each pot was adjusted to its approximate water holding capacity.

Twelve treatments (six treatments of addition of new plant residues and six treatments of no addition of new plant residues) (Table 1) were arranged in a randomized block design with three replicates for each treatment resulting total of 36 pots. Five pre-germinated seeds of maize were planted in each pot and thinned to four plants after 1 week.

\begin{tabular}{|c|c|c|}
\hline No & Code & Remarks (soil previously applied with) \\
\hline 1 & $\mathrm{~N}_{1} \mathrm{~T}_{1}(-)$ & $0.0625 \mathrm{mM} 15 \mathrm{~N}$ labelled rice residues WITHOUT addition of new residue \\
\hline 2 & $\mathrm{~N}_{1} \mathrm{~T}_{1}(+)$ & $0.0625 \mathrm{mM} 15 \mathrm{~N}$ labelled rice residues WITH addition of new residue \\
\hline 3 & $\mathrm{~N}_{2} \mathrm{~T}_{1}(-)$ & $0.250 \mathrm{mM} 15 \mathrm{~N}$ labelled rice residues WITHOUT addition of new residue \\
\hline 4 & $\mathrm{~N}_{2} \mathrm{~T}_{1}(+)$ & $0.250 \mathrm{mM} 15 \mathrm{~N}$ labelled rice residues WITH addition of new residue \\
\hline 5 & $\mathrm{~N}_{3} \mathrm{~T}_{1}(-)$ & $10.0 \mathrm{mM} 15 \mathrm{~N}$ labelled rice residues WITHOUT addition of new residue \\
\hline 6 & $\mathrm{~N}_{3} \mathrm{~T}_{1}(+)$ & $10.0 \mathrm{mM} 15 \mathrm{~N}$ labelled rice residues WITH addition of new residue \\
\hline 7 & $\mathrm{~N}_{1} \mathrm{~T}_{2}(-)$ & $0.0625 \mathrm{mM} 15 \mathrm{~N}$ labelled soybean residues WITHOUT addition of new residue \\
\hline 8 & $\mathrm{~N}_{1} \mathrm{~T}_{2}(+)$ & $0.0625 \mathrm{mM} 15 \mathrm{~N}$ labelled soybean residues WITH addition of new residue \\
\hline 9 & $\mathrm{~N}_{2} \mathrm{~T}_{2}(-)$ & $0.250 \mathrm{mM} 15 \mathrm{~N}$ labelled soybean residues WITHOUT addition of new residue \\
\hline 10 & $\mathrm{~N}_{2} \mathrm{~T}_{2}(+)$ & $0.250 \mathrm{mM} 15 \mathrm{~N}$ labelled soybean residues WITH addition of new residue \\
\hline 11 & $\mathrm{~N}_{3} \mathrm{~T}_{2}(-)$ & $10.0 \mathrm{mM} 15 \mathrm{~N}$ labelled soybean residues WITHOUT addition of new residue \\
\hline 12 & $\mathrm{~N}_{3} \mathrm{~T}_{2}(+)$ & $10.0 \mathrm{mM} 15 \mathrm{~N}$ labelled soybean residues WITH addition of new residue \\
\hline
\end{tabular}

\subsection{Measurements}

Plant height and leaf area were measured at 1, 2, 4, and 8 weeks after planting. At harvest ( 8 weeks), soil $\mathrm{N}$ content, and $\mathrm{N}$ uptake, and ${ }^{15} \mathrm{~N}$ recovery by maize were measured. Maize shoots and roots were separated and then oven-dried at $60 \mathrm{oC}$ for 72 hours, weighed and ground to pass through a $1 \mathrm{~mm}$ sieve. The amount of mineral-N (NH4+ + NO3- in soil was determined using the Kjeldahl distillation method with addition of magnesium oxide and Devarda's Alloy and titration of the distillate trapped into boric acid with standard 0.005 $\mathrm{N}$ H2SO4 (Keeney and Nelson, 1982). Recovery of plant residue $\mathrm{N}$ by maize was estimated by direct ${ }^{15} \mathrm{~N}$ recovery methods as follows,

$$
\% \mathrm{~N} \text { recovery }=\frac{\mathrm{R}_{\text {maize }} x \text { Total maize } \mathrm{N}}{\mathrm{R}_{\text {prunings }} x \text { Crop residue } \mathrm{N} \text { added }} \times 100
$$

Where $\mathrm{R}=$ atom $\%{ }^{15} \mathrm{~N}$ excess. 
Pruning induced priming effects on maize uptake of previously applied ${ }^{15} \mathrm{~N}$-labelled materials were calculated as the difference in ${ }^{15} \mathrm{~N}$ recovery in the treatment where unlabelled new plant residues were added with that where no new plant residues were added.

Priming effect $=\% \mathrm{~N}$ recovery with radditions of new residues $-\% \mathrm{~N}$ recovery without additions of new residues

Measurements of microbial biomass $\mathrm{N}$ were performed (a) at the end of the first cropping cycle for all treatments and (b) at the end of the third cropping cycle in the treatments amended with prunings grown at 10 $\mathrm{mM} \mathrm{N}$ only. The soil microbial biomass was estimated after $24 \mathrm{~h}$ chloroform fumigation and direct extraction with $2 \mathrm{M} \mathrm{KCl}$ (Brookes et al., 1985).

Biomass-N content was determined after Kjeldahl digestion and colorimetric analysis using a $\mathrm{kEN}=0.45$ (Jenkinson, 1988).

\subsection{Soil mineral $\mathbf{N}$}

\section{III.RESULTS AND DISCUSSION}

Soil Mineral Nitrogen (SMN) usually has a bigger effect on crop growth, yields and quality than any other nutrient.In all fertilization and crop rotation treatments, soil mineral $\mathrm{N}$ was relatively high at the start of the growing season,however it decreased with time. After 2 weeks planting in the surface layer of soil, this timing would correspond to the period of rapid crop growth, which would require $\mathrm{N}$ In layers of soil the level of enrichment higher. Thus, provide $\mathrm{N}$ before planting to the growing crop, by releasing nutrients to the top layer of the soil. The highest level of enrichment was at 2 weeks. The result was higher with addition of new soybean residues under $(10.0$ $\mathrm{mM} \mathrm{N}$ concentration) reached to $(450 \mathrm{mg} / \mathrm{kg})$, while the best result for soil mineral $\mathrm{N}$ in rice straw residues was without addition of new rice straw residues under $(0.0625 \mathrm{mM} \mathrm{N}$ concentration) reached to $(340 \mathrm{mg} / \mathrm{kg})$ as shown in Figure (2).

Followed by decline and a significant difference in the results between treatments, however they were equal in the results with addition of new plant residues or without addition of new plant residues in week 4 , The result was higher in rice straw residues under $(0.250 \mathrm{mM} \mathrm{N}$ concentration $)$ and under (10.0 $\mathrm{mM} \mathrm{N}$ concentration) reached to $(18.00 \mathrm{mg} / \mathrm{kg})$, As for the soybean residues the results was higher under $(0.250 \mathrm{mM} \mathrm{N}$ concentration $)$ reached to under $(17.00 \mathrm{mg} / \mathrm{kg})$ as shown in Figure (3).

Then increase the level of enrichment in the eighth week, Incorporation of residue at planting produced the high level of enrichment after 4 until 8 weeks in the topsoil layer. This would correspond to the flowering stage of a long- season cereal or the grain development phase of a short-season legume. The result higher was with addition of new soybean residues under $(0.0625 \mathrm{mM} \mathrm{N}$ concentration) and without addition of new soybean residues under $(0.250 \mathrm{mM} \mathrm{N}$ concentration) reached to under $(30.0 \mathrm{mg} / \mathrm{kg})$, while the best result in rice straw residuas was without addition of new rice straw residues under $(0.0625 \mathrm{mM} \mathrm{N}$ concentration) reached to under $(23 \mathrm{mg} / \mathrm{kg})$ as shown in Figure (4).The $\mathrm{N}$ application as fertilizer or manure supplied most of the initial mineral soil N. Moreover, in the control treatment (without fertilizer) it is likely that the first rains of the season stimulated the microbial activity leading to a high mineralization of soil organic matter resulting in an increase in mineral $\mathrm{N}$. The decrease in soil mineral $\mathrm{N}$ found during the growing season in all treatments is likely due to a decline in organic $\mathrm{N}$ mineralization rates and increased $\mathrm{N}$ uptake/demand by plants, and also probably to losses by leaching and other $\mathrm{N}$ cycling processes. (Bado.B.V.and others 1999)

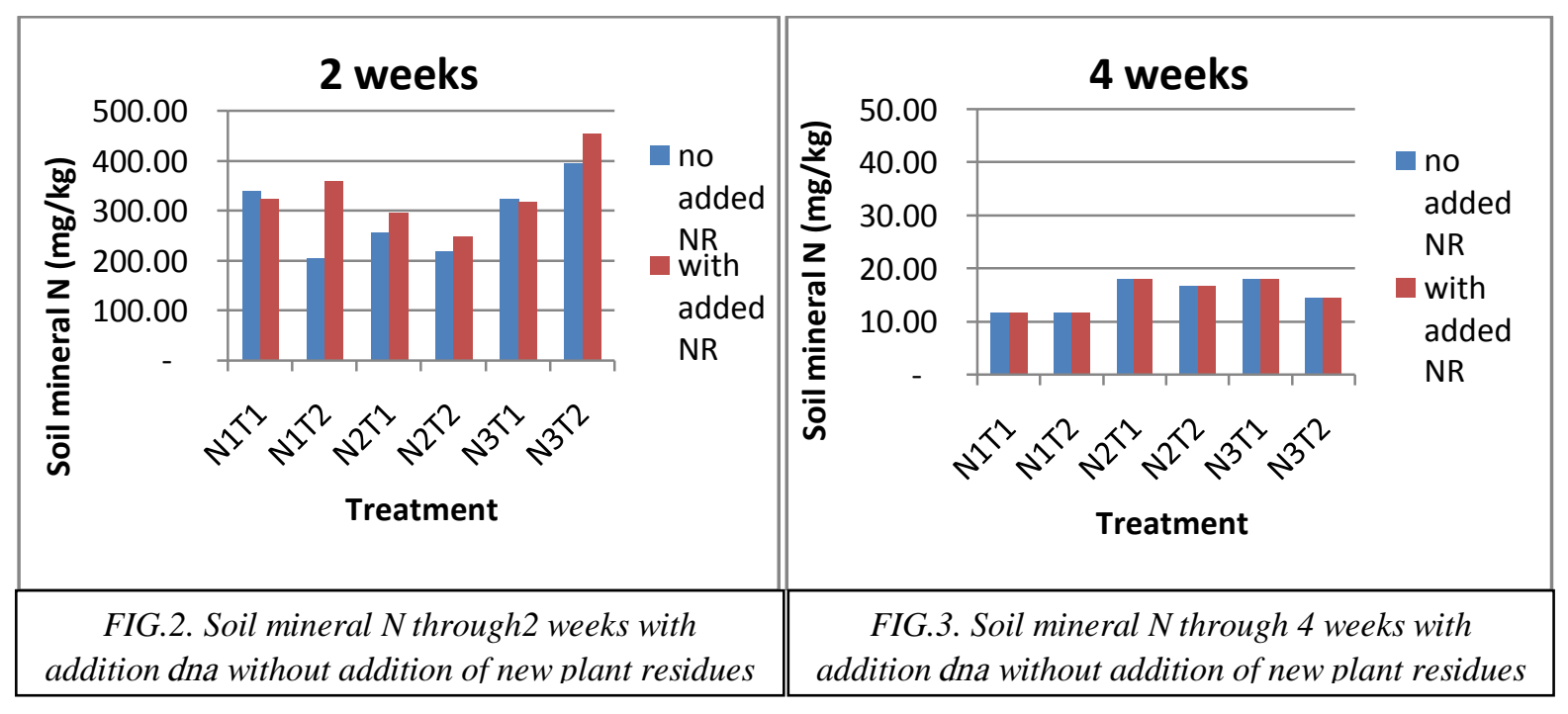




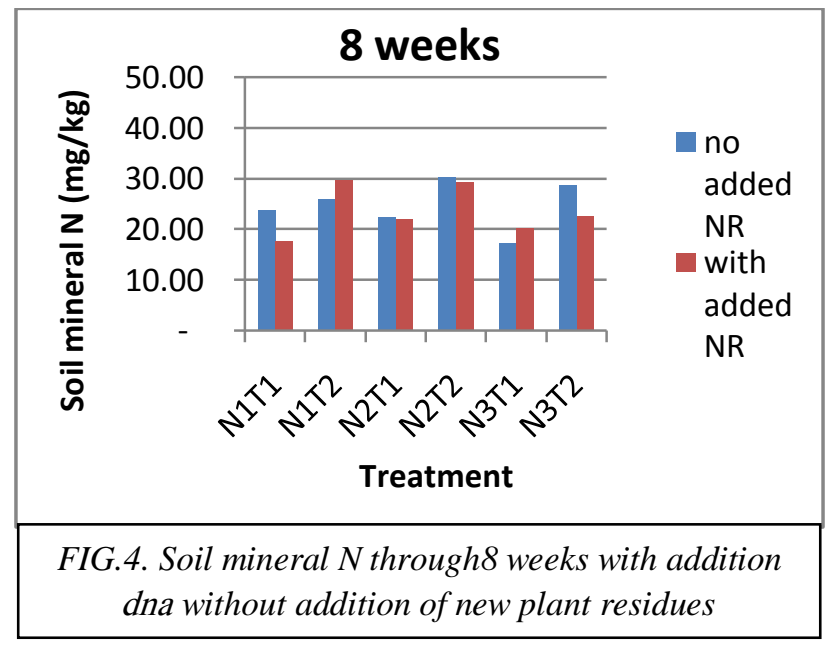

\subsection{Soil $\mathbf{N}$ microbial biomass}

In 2 weeks microbial biomass $\mathrm{N}$ was higher with addition of new straw rice residues $(280 \mathrm{mg} / \mathrm{kg})$ under ( $0.0625 \mathrm{mM} \mathrm{N}$ concentration), while microbial biomass $\mathrm{N}$ with addition of new soybean residue reached to (270 $\mathrm{mg} / \mathrm{kg}$ ) under (10.0 mM N concentration) as show in figure (5). However in 4 weeks the results were higher without addition new plant residues.

Microbial biomass $\mathrm{N}$ was higher without addition of new straw rice residues $(280 \mathrm{mg} / \mathrm{kg})$ under $(0.0625$ $\mathrm{mM} \mathrm{N}$ concentration) similar microbial biomass $\mathrm{N}$ without addition of new soybean residue reached to $(280 \mathrm{mg} / \mathrm{kg})$ under (10.0 mM N concentration) as show in figure (6).

Remained the changes that have occurred in the fourth week because of the rapid decomposition and release and loss of nutrients, as it is until the eighth week and became the best results as it is already in the fourth week except without addition of new soybean residues under (10.0 mM N concentration) reached more than (290 $\mathrm{mg} / \mathrm{kg}$ ) as shown in the figure (7)

The sources of nitrogen for the microbial biomass can be the plant residue itself, the mineral $\mathrm{N}$ already present in soil or recently mineralized, and the recycling soil biomass. It is often assumed that $\mathrm{N}$ coming from the residue and from the recycling biomass is mineralized before being assimilated by the newly formed biomass. However, it has been shown that the soil microflora can directly assimilate significant amounts of organic $\mathrm{N}$ compounds coming from plant residues or from dead biomass (Barak et al., 1990; Hadas et al., 1992; Payne, 1980). Total microbial assimilation also includes reassimilation of $\mathrm{N}$ during biomass recycling. (B. Mary and others 1996)

The rapid loss of mass during the first 2 weeks after application of new plant residues could be attributed to the removal of water-soluble materials. The significantly more rapid decomposition of new plant residues could be attributed to increased microbial activity resulting from higher $\mathrm{pH}$ and more available $\mathrm{N}$.

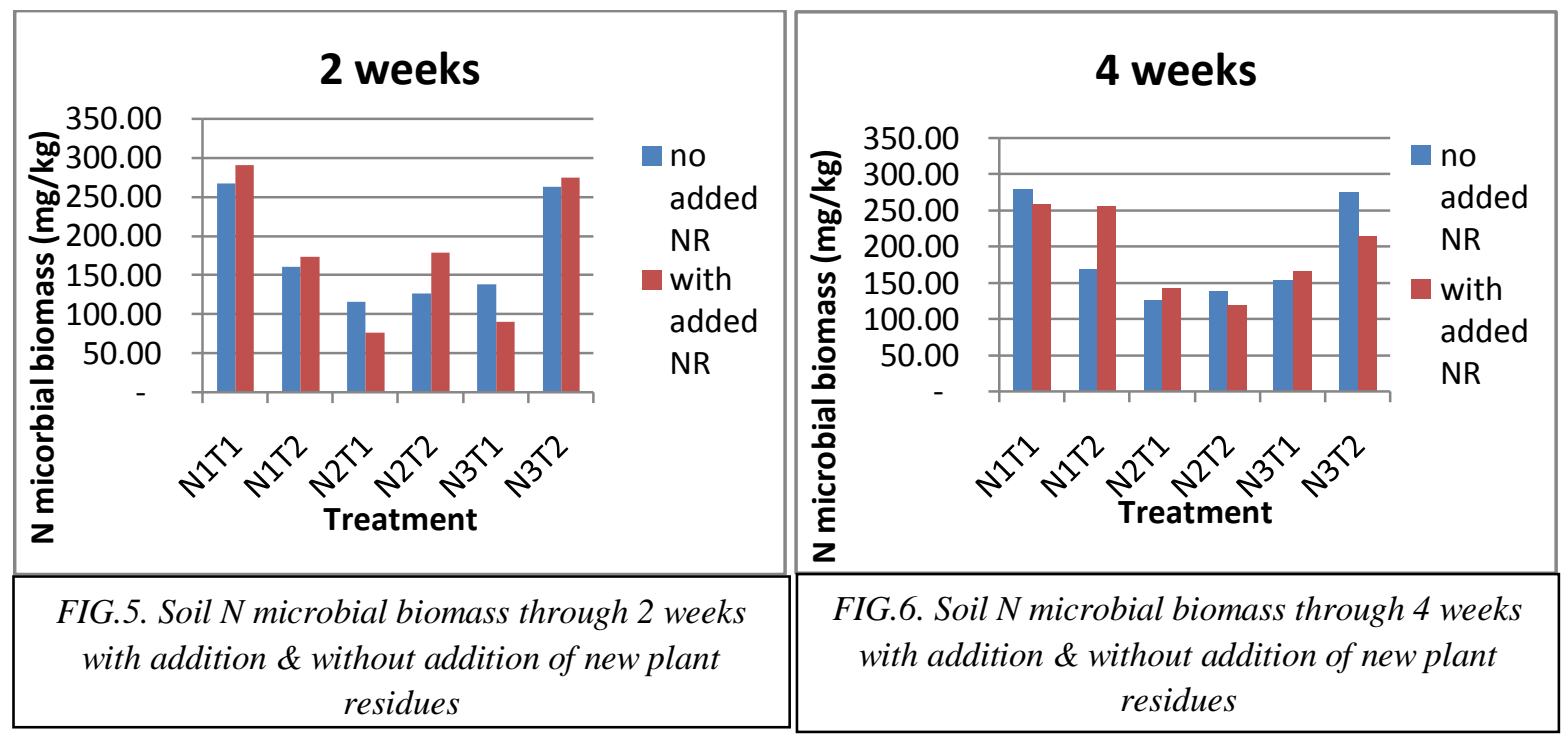




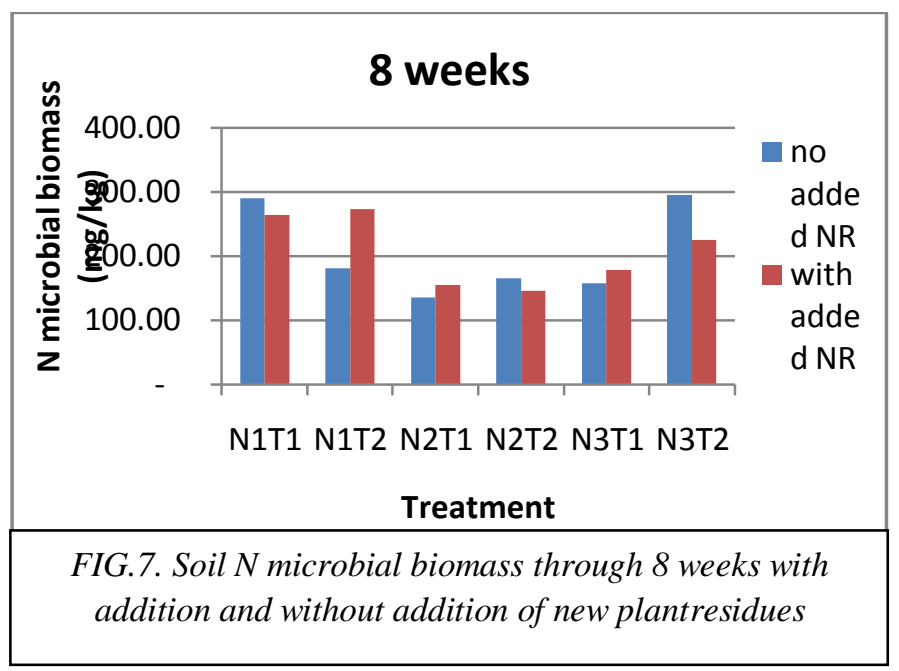

\section{3. Uptake and Recovery of plant residue $\mathrm{N}$ by maize}

Nitrogen uptake by maize was improved by application of crop residues. Compared to the control treatment, application of crop residues increased $\mathrm{N}$ uptake by maize shoot. Jung et al. (1972).Maize grain and residues were analysed for N. Nitrogen was up taken in large amounts by the maize crop.

There were significantly higher in amounts of nitrogen uptake between treatments with addition of new plant residue in rice straw and soybean also exception treatment $\left(\mathrm{N}_{3} \mathrm{~T}_{2}\right)$ under $(10.0 \mathrm{mM} \mathrm{N}$ concentration) in soybean was higher without addition of new plant residue. the results nitrogen uptake by maize shoot with addition rice straw residues were higher in under $(0.250 \mathrm{mM} \mathrm{N}$ concentration $)$ reached to around $(20 \mathrm{mg} / \mathrm{kg})$, while the results nitrogen uptake by maize shoot with soybean residues were higher under $(0.0625 \mathrm{mM} \mathrm{N}$ concentration) reached to (16 $\mathrm{mg} / \mathrm{kg}$ ), which implies that rice straw residues amendment affect the soil fertility more than soybean residues sufficiently to improve growth of the subsequent crop as shown in Figure (8)..Application of crop residue with different $15 \mathrm{~N}$ concentration clearly demonstrated the important role of $\mathrm{N}$ content crop production. The different quality of crop residue influenced soil mineral $\mathrm{N}$, maize growth, dry matter yield and $\mathrm{N}$ uptake. In addition, the crop residue application may favour the activity of microorganism, resulting in a greater $\mathrm{N}$ uptake by maize. (Handayanto.E and others) 2012

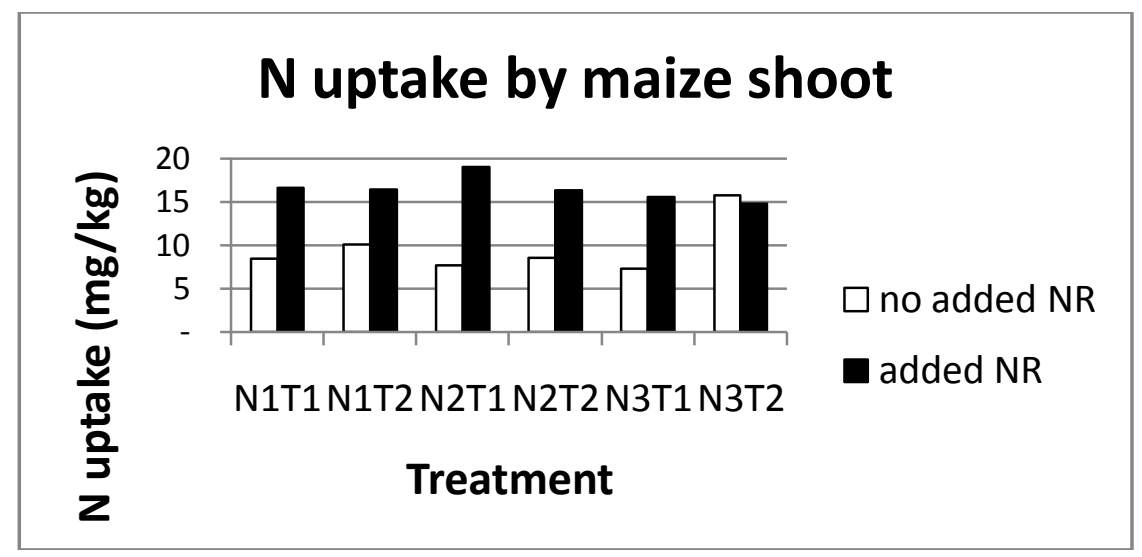

FIG.8. Uptake and Recovery of plant residue $N$ by maize with addition \& without addition of new plant residues

\subsection{Stimulation and Retardation of $\mathbf{N}$ release from plant residues}

Addition of new rice straw residue during maize planting under $(0.0625 \mathrm{mM} \mathrm{N}$ concentration) reached to ($2 \%)$, grown under $(0.250 \mathrm{mM} \mathrm{N}$ concentration) reached to (-4\%), and grown under (10.0 $\mathrm{mM} \mathrm{N}$ concentration) reached to $(-10 \%)$ led to retardation of $\mathrm{N}$ release from plant residues previously and thus to decreased $\mathrm{N}$ uptake by maize.

This negative effect can be due to increase of stabilization of $15 \mathrm{~N}$ organic matter into soil organic matter. Therefore, application of plant residues resulted in a stronger $\mathrm{N}$ binding that led to more $\mathrm{N}$ left in the soils and relatively smaller amounts of $\mathrm{N}$ available for plant uptake, at least in the short term. In contrast to first negative interaction, the addition of new soybean residue during the maize planting grown under $(0.0625 \mathrm{mM} \mathrm{N}$ concentration) reached to (2\%), grown under $(0.250 \mathrm{mM} \mathrm{N}$ concentration) reached to (4\%), and grown under (10.0 
$\mathrm{mM} \mathrm{N}$ concentration) reached to (3\%), led to stimulation of $\mathrm{N}$ release from plant residues previously and thus to decreased $\mathrm{N}$ uptake by maize. This positive interaction could be interpreted as priming effect or added nitrogen interactions. In general, priming effect may be stimulation or retardation of decomposition and recovery of $\mathrm{N}$ following addition of plant residues previously added (Fig.9).

Handayanto.E and others (2010) also reported difference between $\mathrm{N}$ recovery of treatments with or without addition of new unlabelled legume residues at the second experiment (\% $\mathrm{N}$ recovery with addition of new legume residues - \% $\mathrm{N}$ recovery without addition of new legume residues), reflects the stimulatory or retardation effect on $\mathrm{N}$ recovery by the maize crop.

This study indicated the occurrence of priming effect; the maximum effect was only less than $4 \%$ (positive) ot $-10 \%$ (negative) from the initial added $\mathrm{N}$ that was recovered after eight weeks showed when organic matters of different uality were mixed, interaction of quality would occur.

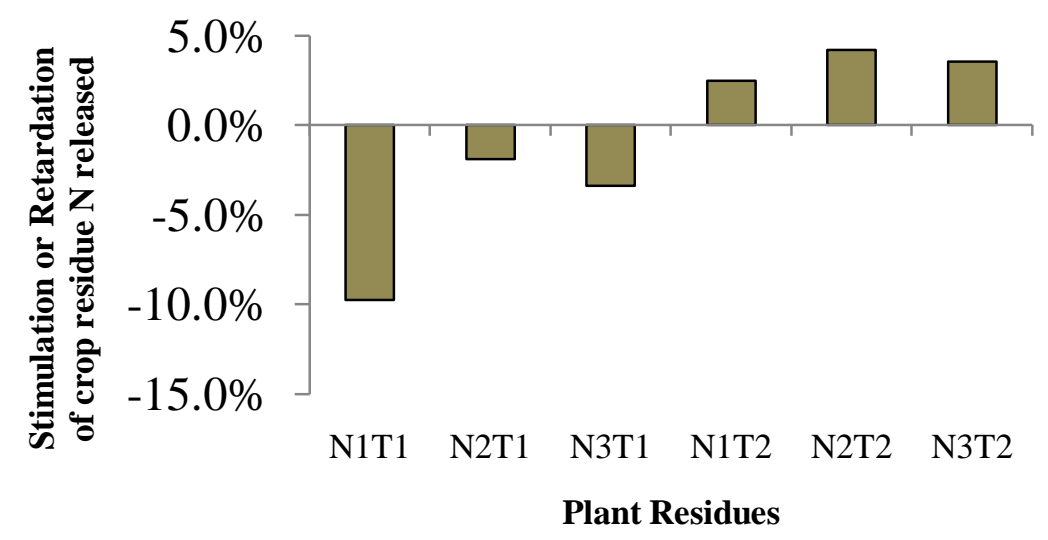

FIG.8. Stimulation and Retardation of $N$ release from plant residues

\subsection{General Discussion}

Cumulative recovery of $15 \mathrm{~N}$ from rice straw residues by maize crop ranged from $0.2 \%$ (grown under $10.0 \mathrm{mM} \mathrm{N}$ concentration) to $0.15 \%$ (grown under $0.250 \mathrm{mM} \mathrm{N}$ concentration). However recovery of $15 \mathrm{~N}$ without addition plant residues showed the best results in terms ranged between $0.15 \%-0.3 \%$. There was no evidence to show that slow decomposing organic matter improved $\mathrm{N}$ mineralization potential of soil organic matter in 8 weeks. Although $\mathrm{N}$ released was high amount from rice straw residues. the amount of $\mathrm{N}$ released from soya bean residues by maize crop was low amount Cumulative from $0.15 \%$ ( grown under $10.0 \mathrm{mM} \mathrm{N}$ concentration) to $0.05 \%$ (grown under $0.0625 \mathrm{mM} \mathrm{N}$ concentration), there was difference in $\mathrm{N}$ release pattern betwen with addition and without addition. Cumulative showed results in terms ranged from 0.1 to 0.05 . It is probable that during 8 weeks of organic matter decomposition, there would only be a small amount of $\mathrm{N}$ released from low quality legume residues as in Figure (9)

Soybean residue decomposes more rapidly than corn residue. This leads to more rapid immobilization and also $\mathrm{N}$ mineralization resulting in an earlier $\mathrm{N}$ release peak than would be seen for corn after corn (Ketterings and others 2007)

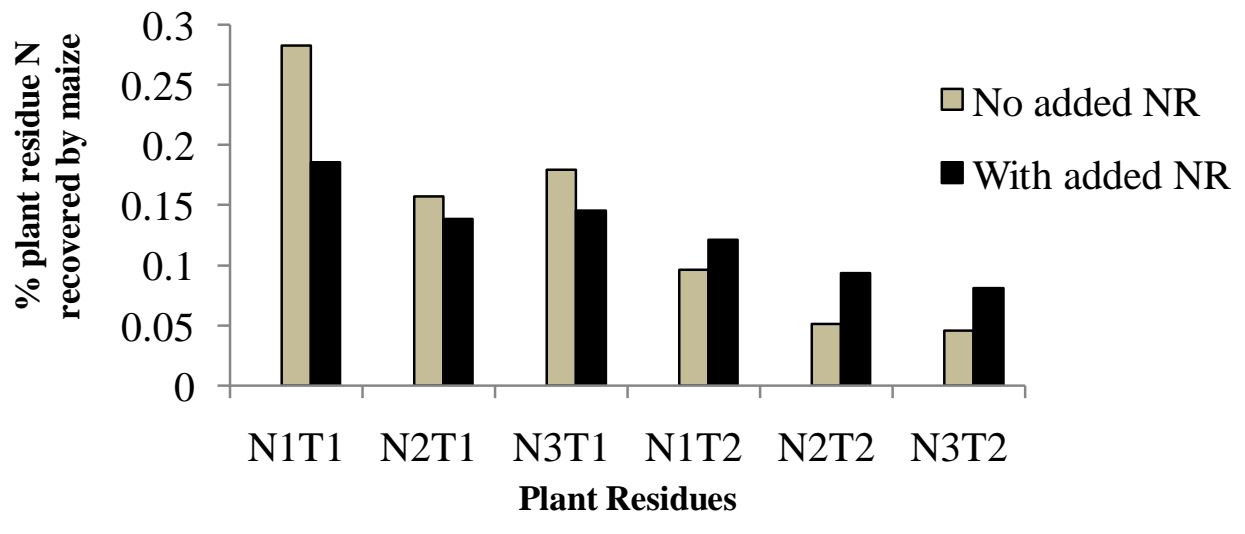

FIG.9. \% plant residue Nrecoveryby maizewith addition \& without addition of plant residues 


\section{RESULTS AND CONCLUSION}

It could be concluded that in the humid tropics, in the period 8 weeks, Effect of plant residues application on nitrogen release from plant residues previously added as rice straw residues would benefit the subsequent crop more than nitrogen release from plant residues previously added as soybean residues, because of rapid decomposition and nitrogen release and loss of nutrients in soybean.

Application of different ${ }^{15} \mathrm{~N}$ concentrations of added crop residues into soil-plant systems affected maize growth and $\mathrm{N}$ recovery by maize. The recovery of $\mathrm{N}$ release from crop residue increased with the increasing ${ }^{15} \mathrm{~N}$ concentration in the crop residues. The amount of $\mathrm{N}$ crop residue taken up by maize was significantly correlated with the initial $\mathrm{N}$ content, polyphenol content, $\mathrm{C}$ : $\mathrm{N}$ ratio, and polyphenol: $\mathrm{N}$ ratio of the crop residues.

\section{ACKNOWLEDGEMENTS}

The experience of working at Soil department Laboratory in the University of Brawijaya at Malang has been one of the most valuable experiences that I have had in my life. I would like to thank to Brawijaya University and I offer my special thanks to all lecturers during my study and all of this research could have not been completed successfully without the assistance of the staff at Soil department Laboratory in the University of Brawijaya. Finally, I thank my mother, father, my wife and my three childern as they constantly encouraged me to finish this thesis successfully.

\section{REFERENCES}

[1] Bado.B.V, Inera, Centre Régional de Recherche Agronomique de Farakô-Ba, Bobo-Dioulasso, Burkina Faso .Currently at Warda, Sahel Station, Saint Louis, Senegal A. Bationo the Tropical Soil Biology and Fertility Institute of CIAT, Nairobi, Kenya

[2] Handayanto, E. and Sholihah, A. (2010). Nitrogen mineralization by maize from previously added legume residues following addition of new legume residues using ${ }^{15} \mathrm{~N}$ labelling technique. Journal of Tropical Agriculture 48 (1-2): 23-27

[3] Handayanto, E., Cadisch, G. and Giller, K.E. (1994) Nitrogen release from prunings of legume hedgerow trees in relation to quality of the prunings and incubation method Plant and Soil 160, 237-248.

[4] Keeney, D. R. and Nelson, D. W. (1982). Nitrogen - inorganic forms. In Methods of Soil Analysis, Part 2, Chemical and Microbiological Properties. Eds. A. L. Page, R. H. Miller, and D. R. Keeney. pp. 643-698. American Society of Agronomy Inc., and Soil Science Society of America Inc., Madison, Wisconsin, USA.

[5] Ketterings.Q, Swink S, Bill Cox, Karl Czymmek 2007“Soybean N Credits"

[6] Sholihah, A, Handayanto, E, Prijono, S. And Utami, S.R. (2012). N Mineralization from Residues of Crops Grown with Varying Supply of ${ }^{15} \mathrm{~N}$ Concentrations. Proceeding International Conference on Environmental, Socio-economic, and Health Impacts of Artisanal and Small Scale Mining. University of Brawijaya, 7-8 Pebruary 2012, pp. 193-200. 